Ferencvárosi Egészségügyi Szolgáltató KKNP Kft., Gasztroenterológia, ${ }^{1}$ Józsefvárosi Szent Kozma Egészségügyi Központ, Diabétesz szakrendelés, ${ }^{2}$ Budapest

\title{
Epekövesség cukorbetegségben
}

\author{
Buzás György Miklós dr. ${ }^{(1,2)}$
}

\begin{abstract}
Osszefoglalás
A cukorbetegség és az epekövesség prevalenciája világszerte növekszik. A cukorbetegség 56\%-kal növeli az epekő kockázatát. Az epekövek 30\%-a genetikai eredetü és a teljesgenom-analizis több olyan eltérést írt le, amelyeknek szerepük van képződésükben. Közös patogenetikai tényezö az obesitas és az inzulinrezisztencia: mindkettö megváltoztatja az epe összetételét, növelve annak litogén indexét és csökkenti az epehólyag motilitását. Az epekö diagnózisában az elsö választandó módszer az ultrahang, mellette a 3D, kontrasztanyagos és funkcionális ultrahang és a szcintigráfia alkalmazható. A CT és az MRI szövödményes esetekben indokolt. Az orális antidiabetikumok többsége nem ellenjavallt epekövességben. Liraglutidkezelés alatt leirtak de novo epekövet. Az inzulinok nem befolyásolják az epekö prevalenciáját és klinikai lefolyását. A statinok hosszú idejü kezeléssel csökkentik az epekö kockázatát, de nem oldják fel a követ. Epeúti kövességben cukorbetegekben is az endoszkópos retrográd cholangio-pancreatographia a választandó terápia kiegészitve az intervencionális endoszkópia módszereivel. A laparoszkópos cholecystectomia átvette a nyilt epemütét helyét cukorbetegekben is, de itt a mütéti konverzió és fertözések kockázata magasabb. Az intervencionális endoszkópia és a laparoszkópos cholecystectomia szövődményei és mortalitása alacsonyabb elhizott cukorbetegekben, mint normális testtömegüekben: ezt „obesitasparadoxonnak" nevezik, okai még nem ismertek. A háziorvos és a diabetológus feladata az epekövesség korai felismerése, ultrahangos szürése és követése és legföképp a mütét megfelelö idejének eldöntése a szövödmények elkerülése miatt.

- Kulcsszavak: diabetes mellitus, endoszkópos retrográd cholangio-pancreatographia, epekö, laparoszkópos cholecystectomia, statin, ultrahang
\end{abstract}

\section{Gallstones in diabetic patients}

Summary: The worldwide prevalence of gallstone disease and diabetes mellitus is increasing. Diabetes increases the relative risk of gallstones by $56 \%$. Gallstones are genetically determined in $30 \%$ of cases and the genome-wide analyses have revealed several genetic changes which could promote gallstone formation. Obesity and insulin resistance, as common pathogenetic factors, can change the composition of bile, increasing its lithogenicity and possibly influencing gallbladder motility. An abdominal ultrasound is the examination of choice in the diagnosis of gallstones, which is completed, if indicated, with contrast-enhanced, 3D or functional ultrasound, cholescintigraphy or cholecystography. CT and MRI are mostly justified in complicated cases. Most oral antidiabetics do not influence bile secretion and gallbladder motility. De novo gallstones however, were described during liraglutide treatment. Insulins do not influence the prevalence and clinical course of gallstone disease. Long-term statin treatment given in adequate doses decreases the risk of gallstones, but does dissolve stones. In diabetics, treating bile duct stones consists of endoscopic retrograde cholangio-pancreatography completed with interventional endoscopic methods. Laparoscopic cholecystectomy replaced open intervention in diabetics. In these patients, the risk of conversion from laparoscopic to open operation and infective complications are higher. The complications and mortality of interventional endoscopic procedures and laparoscopic cholecystectomy are lower in obese than in lean body mass patients, a phenomenon called the "obesity paradox" and unexplained as yet. Family physicians and diabetologist are responsible for the early recognition of gallstones, their ultrasound screening and follow up and making the right decision to operate, in order to prevent complications.

Key words: diabetes mellitus, endoscopic retrograde cholangio-pancreatography, gallstone, laparoscopic cholecystectomy, statin, ultrasound 


\section{Rövidítések}

CCK: kolecisztokinin (cholecystokinine); CI: konfidenciatartomány (confidence interval); DM: diabetes mellitus; ERCP: endoszkópos retrográd cholangio-pancreatographia; FOX01: villásvégü transzkripciós faktor 01 (forkhead transcription factor 01); GLP-1: glukagonszerü peptid-1 (glucagon like peptide-1); IR: inzulinrezisztencia (insulin resistance); LC: laparoszkópos cholecystectomia; LIRKO: liver insulin receptor knock-out; T2DM: 2-es típusú DM (type 2 DM); UH: ultrahangvizsgálat (ultrasonography)

\section{Történeti áttekintés}

Mai életformánk és táplálkozási szokásaink nem kedveznek sem az epekőbetegségnek, sem a diabetesnek: ennek megfelelően mindkét kórkép prevalenciája növekedőben van, tág teret engedve a közös patogenetikai tényezők hatásának.,2,3,4

Mindkét betegség az ókortól ismert, az anatómiai és élettani ismeretek párhuzamosan fejlődtek az évezredek során (1. táblázat).

\section{Epidemiológia}

Az első statisztikákat a 19. század végén közölték: Sir William Osler (1849-1919) belgyógyászati tankönyvében a 19. század végén az Egyesült Államokban 6, Németországban 12\%-os prevalenciát említ. Korabeli hepatológiai tankönyvben ang- liai boncolási adatok 7\%-ot írnak le (3,2\% férfiakban, 10,2\% nőkben), és úgy vélték, hogy a betegség diabetesben sem gyakoribb. Kolozsváron az 1873-1882 közötti időszak boncolási anyagában 1,3\%-ban (1,7\% nők, 0,9\% férfiak) leltek epekövet, 100 évvel később, 1973-1982 között a prevalencia 11,3\% $(17,1 \%$, illetve $6,9 \%)$ volt, tehát a betegség gyakorisága megtízszereződött. ${ }^{5}$

Jelenleg az epekő gyakorisága földrajzi régiónként 3-47\% között változik. ${ }^{1,3}$ Az incidencia ismételt ultrahangos vizsgálatokkal felmérve $0,60 \%$ /év (0,46-1,39\%). ${ }^{1}$ Hazai gyakorisága $10 \%{ }^{2}$

Az Egyesült Államokban a 20-74 év közötti lakosságban 30 millió epeköves beteg van, akiknél évi 750000 cholecystectomiát végeznek, és ez 8-10 milliárd dollár költséget jelent. ${ }^{1}$

Egy metaanalízisben 10 prospektív tanulmány elemzésével 7365198 egyénnél a T2DM 1,56-szo-

1. táblázat. Az epekő és a diabetes mellitus történetének szinopszisa (szemelvényes adatok a szerző A gastroenterológia története [Medicina, 2010] és A diabetológia története [Akadémiai Kiadó, Budapest, 2010] c. könyveiből)

\begin{tabular}{|c|c|c|c|}
\hline Év, korszak & Epekő & Év, korszak & Diabetes mellitus \\
\hline \multirow{2}{*}{ Kr. e. 2-3. évezred } & \multirow{2}{*}{$\begin{array}{c}\text { A Babilonban végzett hepatoszkópiában és } \\
\text { Egyiptomban ismerték az epeköveket }\end{array}$} & Kr. e. 1. évezred & Kínai és indiai ismeretek a cukorbetegségről \\
\hline & & \multirow{3}{*}{ Kr. u. 1. század } & \multirow{3}{*}{$\begin{array}{c}\text { Kappadokkiai Arateusz Alexandriában leírja a } \\
\text { diabetes tüneteit és elnevezi a betegséget; } \\
\text { Aulus Cornelius Celsus leírása }\end{array}$} \\
\hline Kr. e. 6. század & Alexandrosz leírta az epeköveket & & \\
\hline \multirow{2}{*}{ Kr. e. 4 század } & \multirow{2}{*}{$\begin{array}{c}\text { Arisztotelész, Eraszisztratosz felismeri az } \\
\text { epekövesség tüneteit }\end{array}$} & & \\
\hline & & \multirow{2}{*}{ Kr. u. 2 század } & Galénosz igen ritka vesebetegségnek tartja a \\
\hline \multirow[b]{2}{*}{1341} & \multirow{2}{*}{$\begin{array}{l}\text { Gentile da Foligno Padovában boncoláskor } \\
\text { talált epekövet }\end{array}$} & & diabetest \\
\hline & & Kr. u. 12.század & $\begin{array}{c}\text { Maimonidész a diabetest a Nílus iszapos } \\
\text { vizének tulajdonítja }\end{array}$ \\
\hline 1755 & $\begin{array}{c}\text { Albrecht von Haller leírta, hogy egyes } \\
\text { országokban és börtönben lévő embereknél az } \\
\text { epekő gyakoribb }\end{array}$ & 1776 & $\begin{array}{c}\text { Matthew Dobson elsőként mutatja ki a cukrot } \\
\text { a vizeletben }\end{array}$ \\
\hline 1761 & $\begin{array}{c}\text { Giovanni Battista Morgagni először feltételezi } \\
\text { az epekő és az elhízás kapcsolatát }\end{array}$ & 1788 & $\begin{array}{c}\text { Thomas Crawley leírta a pancreasvezetékben } \\
\text { lévő köveket és a diabetest } \\
\text { pancreaseredetűnek tartotta }\end{array}$ \\
\hline 1882 & $\begin{array}{c}\text { Karl Langenbuch elvégzi az első } \\
\text { cholecystectomiát }\end{array}$ & \multirow[t]{2}{*}{$1880-1889$} & \multirow{2}{*}{$\begin{array}{c}\text { Josef von Mering a florizin, Oskar Minkowski } \\
\text { a pancreatectomia utáni diabetest írja le } \\
\text { kutyában }\end{array}$} \\
\hline \multirow{2}{*}{1909} & \multirow{2}{*}{$\begin{array}{l}\text { Ludwig Aschoff szerint az epekövet a } \\
\text { koleszterin-anyagcsere zavara okozza }\end{array}$} & & \\
\hline & & \multirow{2}{*}{ 1920-1922 } & \multirow{2}{*}{$\begin{array}{l}\text { Frederick Grant Banting, Charles Herbert Best } \\
\text { felfedezik az inzulint }\end{array}$} \\
\hline \multirow{2}{*}{1987} & \multirow{2}{*}{$\begin{array}{l}\text { Philip Mouret Párizsban elvégzi az első } \\
\text { laparoszkópos cholecystcectomiát }\end{array}$} & & \\
\hline & & 1994 & Az első humáninzulin-analóg bevezetése \\
\hline
\end{tabular}


rosára (95\%-os CI: 1,26-1,93), azaz 56\%-kal emelte az epekő relatív kockázatát. ${ }^{6}$

\section{Genetika}

Az epekövek 30\%-a genetikai eredetű. A két betegségben számos közös örökletes tényező munkálkodik: ezeket a 2. táblázatban tüntetjük fel. ${ }^{1,5,7}$

A teljes genom vizsgálatával az alábbi, epekőre hajlamosító eltéréseket mutatták ki (ezek listája várhatóan bővülni fog):

- A koleszterol-7 $\alpha$-hidroxiláz gén (CYP7A1) mutációja férfiak epekövességével asszociált: az enzim a koleszterint primer epesavakká alakítja;

- Az $A B C B 4$ gén mutációja a hepatociták kanalikuláris membránján lévő foszfatidilkolin-transzportert módosítja: ez intrahepatikus sludge, epekő képződéséhez és cholestasishoz vezet a biliaris foszfolipidek csökkenése révén; az $A B C G 8$ génen 2 polimorfizmust írtak le, amelyek az epekő kockázatát 1,6-szorosára növelik; ${ }^{7}$

- A CCK-receptor génjének mutációi aberráns CCK-1receptorok keletkezéséhez és motilitászavarhoz vezethetnek, elsősorban elhízott egyénekben;

- A SULT2A1 gén egy enzimet kódol, amely a hidroxiszteroidok és epesavak szulfokonjugációjáért felelős, polimorfizmusa 1,17-szeresére növeli az epekő kockázatát.

Mindezeknek ma még diagnosztikai jelentősége nincs, nem ismert a hatásuk a DM és az epekő együttes előfordulása esetén, de a jövő lehetséges terápiás célpontjai lehetnek.

\section{Patogenezis}

Az epekő képződésében központi jelentőségű a koleszterin biliáris szekréciójának növekedése: ez vagy a koleszterin fokozott szintézisének, vagy az epesavak és foszfolipidek csökkenésének következménye, így a túltelített epében koleszterinnukleáció és -kristályosodás lép fel: e folyamatokat befolyásolják a fenti genetikai tényezők. Az ún. litogén indexet az epében a koleszterin, epesavak és mukoproteinek és a kalcium koncentrációjának aránya határozza meg. Az epehólyag motilitásának csökkenése pangáshoz vezet, ez tovább fokozza az epe túltelítődését. T2DM-ben és obesitasban az inzulinrezisztencia az epehólyag dysmotilitasához vezet, fokozza a májban és a zsírszövetben a lipogenezist, ezen belül a koleszterin és trigliceridek szintézisét és lerakódását, valamint szabad zsírsavak felszaporodását, ezáltal hozzájárulva az epekőképződéshez. ${ }^{8,1}$ Hangsúlyozni kell, hogy 1-es típusú DM-ben az inzulinrezisztencia nem jellemző, bár ritkán itt is kialakulhat, ezért a fenti kórélettani megállapítások elsősorban a T2DM-re vonatkoznak.

Az epekőképződés molekuláris mechanizmusát IR-ben a Joslin klinikán ún. LIRKO egerekben tisztázták. A knock-out állatokban a máj inzulinreceptorait kiirtották, ezáltal a villásvégű transzkripciós faktor O1 (FOXO1) növelte az Abcg5 és Abcg8 koleszterintranszporterek expresszióját és az epe koleszterintartalmát. Emellett a kísérleti IR csökkenti a Cyptb1 epesavszintetizáló enzim expresszióját és gátolja a farnezoid $\mathrm{X}$ receptort. A két mechanizmus litogén epe képződéséhez vezet: ezek az állatok 3 hónap alatt 100\%-ban epekövet termelnek. Emberben az $A B C G 5$ és 8 gének a 2. kromoszomán helyezkednek el és géntermékük szintén a koleszterin transzportját végzi. A FOXO1 a koleszterintranszportereken kívül

\section{2. táblázat. A genetikai tényezők szerepe epekövességben és cukorbetegségben ${ }^{1,3,4,5}$}

\begin{tabular}{|c|c|c|}
\hline Genetikai tényező & Epekő gyakorisága (\%) & Diabetes mellitus gyakorisága \\
\hline Családi halmozódás & $\begin{array}{c}\text { Epekőbetegek elsőfokú rokonainál a betegség 2-3-szor } \\
\text { gyakoribb; monozigóta ikrekben a konkordancia 65\%-os, } \\
\text { dizigótákban 15\%-os }\end{array}$ & $\begin{array}{c}\text { Monozigóta ikrekben a DM gyakorisága } 65 \% \text {, } \\
\text { dizigótákban } 22 \%\end{array}$ \\
\hline Életkor & $\begin{array}{l}50 \text { év alatt az epekő gyakorisága 8,8-12\%, } 50 \text { év felett } \\
\qquad 36-40 \%\end{array}$ & A T2DM gyakorisága 30 év felett világszerte növekszik \\
\hline Nem & Férfiaknál az epekő gyakoriság 1,9-4,3\%, nőknél 18-27\% & $\begin{array}{l}\text { Nóknél az epekő gyakorisága 1,5-1,8-szor magasabb és } \\
\text { az elhízással és szülések számával tovább növekszik }\end{array}$ \\
\hline Vércsoport & $\begin{array}{c}\text { A és/vagy Rh-negatív vércsoport esetében az epekő } \\
\text { gyakoribb }\end{array}$ & $\begin{array}{l}\text { A T2DM gyakoribb B és ritkább } 0 \text { vércsoportban, az Rh- } \\
\text { státus nem befolyásolja a T2DM gyakoriságát }\end{array}$ \\
\hline Etnikai származás & $\begin{array}{l}\text { Gyakorisága Pima indiánoknál 50\%, fehér embereknél } \\
\text { 20-30\%, afrikaiaknál 5\% és kelet-ázsiai egyéneknél } \\
5-20 \%\end{array}$ & $\begin{array}{l}\text { Pima indiánoknál a DM és szövődményei gyakoriak, } \\
\text { navaro indiánoknál a DM gyakoribb, de a szövődmények } \\
\text { ritkák }\end{array}$ \\
\hline
\end{tabular}


a gluconeogenesist szabályozó enzimek fokozott expresszióját is okozza, így összekapcsolva az IR, az obesitas, a DM és az epekő keletkezését: a folyamat minden részlete emberben még nem tisztázott. ${ }^{9}$

\section{Diagnózis}

Az epekövek túlnyomó része tünetmentes, felfedezésük gyakran incidentálisan, más okból végzett UH során történik. Prospektív tanulmányok kimutatták, hogy 5, 10, 15 év alatt az esetek 10, 15 és $18 \%$-ában jelentkeznek tünetek, leggyakrabban epekólika formájában, amely 38-50\%-ban ismétlődik, ezért fel kell ajánlani a profilaktikus laparoszkópos cholecystectomiát (LC) a szövődmények megelőzése érdekében. DM-ben a tünetet okozó epekövek aránya 5 év alatt $15 \%$, a szövődmények és a mortalitás nem különbözik a nem cukorbetegekétől, ezért tünetmentes DM-ben nem javasolt a profilaktikus LC. ${ }^{1}$ A több évtizede fenn- álló epekő és a diabetes hajlamosít az epehólyagrákra, a műtét ilyenkor meggondolandó panaszmentes esetben is.

$\mathrm{Az}$ orális és intravénás cholecystographia több évtizedes korszaka után jelenleg az epekő gyanújában az első választandó vizsgálat az ultrahang.

Az első sikeres epekőkimutatást George Ludwig bethesdai hallgató végezte, aki kutyaizomba ágyazott emberi epekövet ábrázolt 1948-ban pulzus-echo módszerrel.

A lege artis végzett vizsgálat ${ }^{10}$ alkalmas nemcsak a cholelithiasis kimutatására, de kiértékeli a hólyagfal vastagságát és kóros eltéréseit (gyulladás? polip? tumor?), az epeutak állapotát (tágulat? kövesség?), leírja a máj és pancreas elváltozásait is.

Avatott vizsgálókezekben és megfelelő készülékkel az UH érzékenysége $2 \mathrm{~mm}$-nél nagyobb kövekben 95-98\%, fajlagossága 95\%, de a túlterheltség, tapasztalatlanság, elavult/rosszul beállított készülék, hibás vizsgálati technika, figyelmetlenség

3. táblázat. Az epekő diagnosztikai módszerei ${ }^{1,10,11,12,13}$

\begin{tabular}{|c|c|c|}
\hline Módszer & Indikáció & Megjegyzés \\
\hline 2D ultrahang & $\begin{array}{c}\text { Első választandó vizsgálat az epekő és szövődményeiben, } \\
\text { általánosan elérhető és ismételhető, sürgősségben is } \\
\text { alkalmazható }\end{array}$ & Vizsgáló-, készülék- és betegfüggő! \\
\hline 3D ultrahang & $\begin{array}{c}\text { Funkcionális UH-ként alkalmazható az epehólyag-ürülés, a } \\
\text { kövek térfogatának, formájának meghatározására (pld. kőoldó } \\
\text { kezelés előtt és után) }\end{array}$ & $\begin{array}{l}\text { Idem, hozzáférhetősége korlátozott, kevés a } \\
\text { módszerben tapasztalt szakember }\end{array}$ \\
\hline Endoszkópos UH & $\begin{array}{c}\text { Elsősorban az epeúti kövesség és társult pancreaselváltozások } \\
\text { kimutatásában indokolt, önmagában vagy ERCP-vel. } \\
\text { Érzékenysége 95\%, fajlagossága 97\% }\end{array}$ & $\begin{array}{l}\text { Jelentős endoszkópos és UH-tapasztalatot } \\
\text { igényel, végzése centrumokban optimális }\end{array}$ \\
\hline Kontrasztanyagos UH & $\begin{array}{c}\text { Az epehólyagfal szerkezetének és vérkeringésének } \\
\text { meghatározásában az epekővel társult gyulladás/epehólyagrák } \\
\text { diagnózisában hasznos }\end{array}$ & $\begin{array}{l}\text { A DM mind az epekő, mind az epehólyagrák } \\
\text { kockázatát növeli. UH-kontrasztanyagok } \\
\text { adhatók csökkent vesefunkcióban is }\end{array}$ \\
\hline Cholecystographia & $\begin{array}{l}\text { UH-val nem kimutatható kövek vagy adenomyomatosis, tumor } \\
\text { esetében indokolt; érzékenysége } 95 \% \text {, de az esetek } 25 \% \text {-ában } \\
\text { több ok miatt a kontrasztanyag nem ürül ki az epébe }\end{array}$ & $\begin{array}{l}\text { DM-ben csak ép vesefunkcióval és a } \\
\text { metformin elhagyásával alkalmazható! }\end{array}$ \\
\hline $\begin{array}{l}\text { Hepatobiliáris scintigráfia } \\
\text { (HIDA, DIAA) }\end{array}$ & $\begin{array}{c}\text { A ductus cysticus átjárhatóságának kimutatásában } \\
\text { érzékenysége } 95 \% \text {-os. CCK-stimulálással az epehólyag ejekciós } \\
\text { frakciója mérhető }\end{array}$ & $\begin{array}{l}\text { T2DM-ben igazolta az epehólyag ürülési } \\
\text { zavarát és arany standardként alkalmazható }\end{array}$ \\
\hline $\begin{array}{l}\text { ERCP } \pm \text { intervencionális } \\
\text { endoszkópia }\end{array}$ & $\begin{array}{l}\text { Epeúti kövesség kimutatásában érzékenysége 90-95\%, } \\
\text { fajlagossága 90\% }\end{array}$ & $\begin{array}{l}\text { Invazív, kontrasztanyag adásával jár, } \\
\text { szövődmények lehetségesek }\end{array}$ \\
\hline MRCP & $\begin{array}{l}\text { Pontossága egyezik az ERCP-vel, kimutatja az intrahepatikus } \\
\text { epeutakat is és a környező szervekben a szövődményeket }\end{array}$ & $\begin{array}{c}\text { Drága, nem mindenütt elérhető; DM-ben } \\
\text { ugyanazok a szabályok, mint CT esetén } \\
\text { (vesefunkció, metformin) }\end{array}$ \\
\hline Spirál-CT & $\begin{array}{l}\text { Szövődmények (tályog, perforáció, pancreatitis) kimutatásában } \\
\text { indokolt; szövődménymentes esetekben luxus }\end{array}$ & Lásd az MRCP-nél \\
\hline
\end{tabular}

DIAA: hidroxi-diizopropilimino-diecetsav (diacetic hydroxi-diisopropilamine acid); HIDA: hidroxi-imino-diecetsav (hydroxi-imino diacetic acid); MRCP: mágnes rezonancia cholangio-pancreatographia 
miatt még nagy követ is el lehet nézni: ilyenkor ismétlés javasolt jobb személyi és műszerezettségi körülmények között.

A 2D módban végzett vizsgálat az esetek túlnyomó többségében elégséges a diagnózishoz, de megfelelő indikáció esetén kiegészíthető a 3. táblázatban feltüntetett módszerekkel. A háziorvos feladata, hogy a cukorbeteget lehetőleg a betegség kezdetén vagy jellemző tünetek esetén UHvizsgálatra irányítsa: ezzel nemcsak az epekő, de a manapság oly gyakori nem alkoholos zsírmáj is kimutatható. Ismételten végezve felbecsülhető az epekő növekedése is (1-2 mm/év). Populációs felmérésekben az UH a prevalencia becslésére is használható. ${ }^{11,12,13}$

\section{Az antidiabetikus kezelés hatása az epekövességre}

A diabetesben adott gyógyszerek általában nem befolyásolják az epekőbetegséget. A főbb gyógyszercsoportokból a készítmények többsége (akarbóz, metformin, glimeripirid, gliclazid, inkretinek, nátrium-glukóz transzporter-2 gátlók) a vesén keresztül ürülnek, így nem befolyásolják az epetermelést, kőképződést és a meglévő kő okozta tüneteket, így adásuk epeköves betegekben nem ellenjavallt. Az epén át ürülő gliquidonról nincs terhelő adat.

Az 1960-as években Káldor Antal (1925-2005) és Pogátsa Gábor állatkísérletben, majd emberben mutatták ki, hogy a karbutamid és tolbutamid növeli az epetermelést. ${ }^{14,15} \mathrm{E}$ vegyületek serkentik az epesavak termelését: ebben szerepet játszhat az, hogy részben a májon át, az epével ürülnek. Hasonló meghatározások a II.-III. generációs sulfanylureákkal nem történtek.

A metformin - sok előnyös tulajdonsága mellett - serkenti a glukagonszerű peptid-1 epesavak mediálta termelését az L-sejtekben, ami hozzájárulhat vércukorcsökkentő hatásához. ${ }^{16}$ Obez egérben kimutatták, hogy a pioglitazon, bár csökkenti az IR-t, gátolja az epehólyag-motilitást ${ }^{17}$ de nem ismert, hogy emberben van-e ilyen hatása. A sitagliptin T2DM-ben növeli a máj epetermelését és nem befolyásolja az epehólyag-motilitást: a többi dipeptidilpeptidáz-gátlónál ilyen hatást nem írtak le. ${ }^{2}$ A liraglutid, bár nem befolyásolja az epehólyag-ürülést, a kezelés során leírták a de novo epekőképződést: ${ }^{18}$ alkalmazási előirata szerint epekövességben ellenjavallata nincs.

A hagyományos és az inzulinanalóg-kezelés egyik formája sem nem befolyásolja az epekő prevalenciáját és klinikai lefolyását.

\section{A lipidcsökkentö kezelés és az epekövesség}

A nyugati országokban a statinok a legnépszerủbb gyógyszerek közé tartoznak: 1987-es bevezetésük óta használatuk megtízszereződött. Értelmiségi körökben statinpárti és statinellenes csoportok alakultak ki. A statinok a koleszterinszintézis gátlása révén csökkentik az epe koleszterintartalmát. Állatkísérletekben a statinok megelőzték az epekő képződését. A HDL-koleszterin emelkedése és a trigliceridszint csökkenése hozzájárul a litogén index kedvező módosulásához, és feltételezik, hogy a pleiotropia révén a statinok a koleszterinszintézis csökkenésétől függetlenül is hatnak (gyulladásgátlás, inzulinérzékenység növelése). Néhány negatív eredménnyel járó, kis esetszámú és rövid követési idejü tanulmány után az utóbbi években, 2014-ben kínai metaanalízisben 6222687 eset alapján az esélyhányados szignifikáns csökkenését mutatták ki (esélyhányados: 0,86, 95\%-os CI: 0,77-0,97). A különböző statinok között e téren nincs különbség. Kis dózisban, rövid ideig adott statinnak ilyen hatása nincs. ${ }^{19}$ A statint szedő betegnél csökkent a cholecystectomiák száma, tehát adásuknak kedvező tüneti hatása van, és a mütéti idő $10 \%$-kal csökken. ${ }^{20}$ Történtek kísérletek kőoldással is, de az eddigi eredmények ellentmondásosak.

A koleszterin felszívódását az ezetimib a Niemann-Pick C1-szerű receptorok blokkolásával gátolja, de ez nem befolyásolta az epekő gyakoriságát annak ellenére, hogy a máj epecanalicusain is van Niemann-Pick-receptor, amely felszívja a koleszterint az epéből. ${ }^{21}$

A lipidcsökkentő kezelés hajnalán, az 1960-as években a clofibráttal végzett első prevenciós tanulmányban kimutatták, hogy a gyógyszer 7-8-szorosára növeli az epekő kockázatát. Nő az új diabetes mellitus és a cholecystectomiák gyakorisága is, ezért koleszterincsökkentő és kardiovaszkuláris preven- 
tív hatása ellenére a clofibrát használatát felfüggesztették: az Edinburghban szervezett vizsgálatban részt vett Lamm György az akkori Országos Kardiológiai Intézetből, mivel a szocialista országból „könnyebb volt beteget bevonni”. ${ }^{22}$ A clofibrát helyét a fibrátok vették át, de 40 éves alkalmazásuk alatt az epekő vonatkozásában ellentmondásos eredmények születtek.

\section{A kőoldó kezelés és a diabetes mellitus}

Az epekő kémiai feloldásának célja a műtét elkerülése: az ötlet több mint 100 éves, amikor kémikusok a műtétileg eltávolított köveket számtalan vegyszerben próbálták feloldani. A kőoldás elve, hogy az epe litogén összetételét megváltoztassák úgy, hogy a koleszterinkövek feloldódjanak. Az 1970-80-as években használt kenodezoxikólsav mellékhatásai miatt nem vált be, helyette a medveepéből izolált urzodezoxikólsav került forgalomba. A szigorú beválogatási kritériumok mellett (szövődménymentes epekő, UH-val vagy szcintigráfiával igazolt megtartott epehólyag-müködés, $1 \mathrm{~cm}$-nél kisebb, kalciumot, biliáris pigmenteket nem tartalmazó kő) 6 hónap alatt a kövek 37\%a oldódik fel, de 2 éven belül 50\%-ban recidiválnak. Nincs adat az urzodezoxikólsav hatásosságáról diabetesben, de állatkísérletekben kimutatták, hogy a vegyület csökkenti a hyperglykaemia okozta oxidatív stresszt nephropathiában, védő hatása van a retinopathiában és érelmeszesedésben, emberben pedig kedvező hatású a nem alkoholos zsírmáj kezelésében. ${ }^{23}$

\section{Endoszkópos retrográd cholangio- pancreatographia diabetesben}

Az epeúti kövesség megoldásának standard módszere az ERCP + kiegészítő eljárásai (sphinctero-papillotomia, Dormia-kosaras kőextrakció, a pancreasvezeték kanülálása, citológiai mintavétel, stent behelyezése stb.). ${ }^{24}$

Az eljárás szövődményei a post-ERCP pancreatitis és a vérzés. A diabetes mellitus a post-ERCP pancreatitis kockázatát érdekes módon csökkenti: a michigani Ann Arbor egyetemen 5254 betegben 8264 ERCP-t végeztek, és a cukorbetegnél 8,1\%ban, a kontrollcsoportnál 16,1\%-ban $(\mathrm{p}=0,006)$ lépett fel e szövődmény. ${ }^{25}$ Diabetesben a súlyos
post-ERCP pancreatitis ritkább volt $(4,5 \%)$, mint hypertoniás vagy szívbeteg egyéneknél (18-22\%). Más, jóval kisebb tanulmányokban azonban a diabetes a post-ERCP pancreatitis kockázati tényezője volt. ${ }^{26}$

Spanyol tanulmányban 23002 T2DM-es és 103883 nem cukorbeteg személyen végzett ERCP során a kórházi mortalitás alacsonyabb volt a cukorbetegekben, különösen az elhízottakban: ${ }^{27}$ hasonló jelenséget írtak le elhízott T2DM-es betegekben perkután coronariaintervenciók után, és azt „obesitas-paradoxonnak” nevezték. ${ }^{28} \mathrm{Nem}$ ismert, hogy obesitasban melyek a védő tényezők. A post-sphincterotomiás vagy papillotomiás vérzés az ERCP-k 1,5-2\%-ában lép fel, az esetek 20\%ában a vérzés recidivál. A vérzés ellátását számos betegségfüggő (nehezen kanülálható papilla, operált gyomor, beékelődött kő, malignitás, icterus, sürgősségi vizsgálat) és vizsgálófüggő (egyéni tapasztalat, a vizsgált esetek száma, a rendelkezésre álló kellékek minősége) tényező, valamint a komorbiditások is befolyásolják (szív, keringési rendszer, tüdő állapota, vese- és májfunkció), de a T2DM nem befolyásolja negatívan a vérzést és az endoszkópos hemosztázis eredményét.

\section{Cholecystectomia diabetes mellitusban}

Az 1882-ben bevezetett nyílt cholecystectomiát mára majdnem teljesen helyettesítette az 1986-ban először végzett laparoszkópos műtét, mivel rövidebb ideig tart, csökkenti a posztoperatív panaszok és szövődmények arányát, a kórházi kezelés időtartamát és ezáltal a költségeket, eredménye esztétikusabb. A DM egyike azon tényezőknek, amelyek a műtét konverziójára hajlamosítanak (azaz a sikertelen LC után nyílt cholecystectomia). Nagy esetszámú finn retrospektív tanulmányban a DMben végzett műtétekben a konverziót igénylő betegek aránya 33,8\% volt és 2,0-szeresre (95\%-os CI: 1,0-3,5) növelte annak kockázatát. ${ }^{29}$ Spanyolországban 2003-2013 között 611533 epehólyagműtétet végeztek, 78227-et $(12,8 \%)$ cukorbetegekben. $\mathrm{Az}$ említett időszakban a T2DM-ben végzett LC aránya fokozatosan növekedett, a kórházi mortalitás aránya kezdetben növekedett, majd csökkent. $\mathrm{Az}$ „obesitas-paradoxon” itt is jelen volt: kövér cukorbetegekben az eredmények jobbak voltak. ${ }^{30} \mathrm{~A}$ 
T2DM kockázati tényezője a műtét utáni sebfertőzéseknek. A T2DM nem befolyásolta az LC műtéti időtartamát. ${ }^{31}$

Műtét előtt diabetológusi konzílium szükséges. Mivel a mütéti időtartam rövid és a táplálkozás már a 2.-3. napon elkezdhető, általában nincs szükség az orális kezelés inzulinra való átállítására, de ez mindig egyéni mérlegelést igényel.

Összefoglalásul, a háziorvos és a diabetológus feladata cukorbetegekben az epekövesség fokozott kockázatának ismerete, a betegek ultrahangos szűrése és követése, a megfelelő műtéti időzítés a szövődmények elkerülésére.

\section{Köszönetnyilvánítás}

A szerző köszöni Oláh Ilonának (Semmelweis Egyetem, Élettani Intézet) az irodalomkutatást, Douglas Arnott úrnak (EDMF Language Services Kft) az angol összefoglaló lektorálását, Józan Jolánnak a szövegszerkesztést.

Közlésre érkezett: 2017. június 9.

Közlésre elfogadva: 2017. november 2.

\author{
A levelezésért felelős szerző: \\ Dr. Buzás György Miklós \\ Józsefvárosi Szent Kozma Egészségügyi Központ \\ Diabétesz szakrendelés \\ 1084 Budapest, Auróra utca 22-28 \\ E-mail:drbgym@mail.com
}

\section{Irodalom}

1. Wang DQ-H, Afdhal NH: Gallstone disease (in: Feldman M, Friedman LS, Brandt LJ Iszerk.I: Sleisinger and Fordtran's Gastrointestinal and Liver Disease, Pathophysiology/Diagnosis/Management, 10. kiadás, 1. kötet, Elsevier-Saunders, 2016), pp. 1100-1133.

2. Lonovics ): Az epehólyag és az epeutak betegségei (in: Tulassay Zs /szerk. I: A belgyógyászat alapjai, 5. kiadás, 2016), pp. 1107-1117.

3. Shabanzadeh DM, Sørensen LT, Jørgensen T: Determinants for gallstone formation - a new data cohort study and systematic review with meta-analysis. Scand I Gastroenterol 2016; 51: 1239-1248. doi:10.1080/00365521.2016.1182583

4. Meo SA, Rouq FA, Surava F, Zaidi SZ: Association of ABO and Rh blood groups with type 2 diabetes mellitus. Eur Rev Med Pharmacol Sci 2016; 20(2): 237-242.

5. Dumitrasçu D, Acalovschi M, Grigorescu M: Litiaza biliară. Editura Academiei, Bucureşti, 1989; pp. 14-22.

6. Aune D, Vatten L: Diabetes mellitus and the risk of gallbladder disease: a systematic review and meta-analysis of prospective studies. I Diab Complications 2016; 30: 368-373. doi:10.1016/j.jdiacomp.2015.11.012

7. Joshi AD, Andersson C, Buch S, Stender S, Noordam R, Weng L-C, et al.: Four susceptibility loci for gallstone disease identified in a meta-analysis of genome-wide association studies. Gastroenterology 2016; 151: 351-363. doi:10.1053/j.gastro.2016.04.007

8. Nakeeb A, Comuzzie AG, Al-Azzawi H, Sonnenberg GE, Kissebah AH, Pitt HA: Insulin resistance causes human gallbladder dysmotility. I Gastrointest Surg 2006; 10(7): 940-948. doi:10.1016/j.gassur.2006.04.005

1. Winkler G, Wittman I (szerk.): Az inzulinrezisztencia és klinikai vonatkozásai. Springmed Kiadó, Budapest, 2017.

9. Biddinger SB, Haas JT, Bezy O, Jing E, Zhang W, Unterman TG, et al.: Hepatic insulin resistance directly promotes formation of cholesterol gallstones. Nature Med 2008; 14(7): 778-782. doi:10.1038/nm1785

10. Harkányi Z: Komplex hasi ultrahangvizsgálatok (in: Harkányi Z, Morvay $Z$ Iszerk.I: Hogyan vizsgáljunk ultrahanggal, Medicina Könyvkiadó Zrt., Budapest, 2016), pp. 53-60.

11. Hausken T, Søndena K, Svebak S, Gilia OH, Olaffson S, Odegaard S, et al: Common pathogenetic mechanisms in symptomatic uncomplicated gallstone disease and functional dyspepsia: volume measurement of gallbladder and antrum using three-dimensional ultrasonography. Dig Dis Sci 1997; 42(23): 2505-2512. doi:10.1023/A:1018860511702

12. Wang W, Fei Y, Wang F: Meta-analysis of contrast-enhanced ultrasonography for the detection of gallbladder carcinoma. Med Ultrason 2016; 18(3): 281-287. doi:10.11152/mu.2013.2066.183.wei

13. Yang CC, Sun SS, Lin CC, Kao A, Lee CC: Evidence of impaired gallbladder function in patients with non-insulin dependent diabetes mellitus by quantitative cholescintigraphy. I Diabetes Complications 2002; 16(5): 347-351. doi:10.1016/51056-8727(01)00218-5

14. Káldor A, Pogátsa G: Effect of tolbutamide on bile secretion. Lancet 1960; ii: 1094 (szerkesztöségi levél).

15. Káldor A, Pogátsa G, Buzási Gy: Adatok a Carbutamid "cholagog" hatásához. Magyar Belorv Arch 1961; 14: 21-23.

16. Kårhus ML, Brønden A, Sonne DP, Visbøll T, Knop FK: Evidence connecting old, new and neglected glucose-lowering drugs to bile acid-induced GLP1 secretion: a review. Diabetes Obes Metab 2017; 19(9): 1214-1222. doi:10.1111/dom.12946

17. Al-Azzawi HH, Mathur A, Lu D, Swartz-Basile DA, Nakeeb A, Pitt HA: Pioglitazone increases gallbladder volume in insulin-resistant obese mice. J Surg Res 2006; 136(2): 192-197. doi:10.1016/j.jss.2006.06.022 
2. Smits MM, Tonneijck L, Muskiet MHA, Hoekstra T, Krasmer MHH, Diamant $M$, et al: Biliary effects of liraglutide and sitagliptin, a 12-week randomised placebo-controlled trial in type 2 diabetes patients. Diabetes Obes Metab 2016; 18: 1217-1225. doi:10.1111/dom.12748

18. Korkmaz H, Araz M, Alkan S, Akarsu E: Liraglutide-related cholelithiasis. Aging Clin Exp Res 2015; 27(5): 751-753. doi:10.1007/540520-015-0335-2

19. Kan HP, Guo WB, Tan YF, Zhou J, Liu CH, Huang YQ: Statin use and risk of gallstone disease: a meta-analysis. Hepatol Res 2015; 45(9): 942-948. doi:10.1111/hepr.12433

20. Pulkinen J, Erskelinen $M_{1}$ Kiviniemi $V$, Kotilainen $T$, Pöyhönen $M$, Kilpeläinen $L$, et al.: Effect of statin use on outcome of symptomatic cholelithiasis: a case-control study. BMC Gastroenterology 2014; 14: 119. doi:10.1186/1471-230X-14-119

21. Stein A, Hermoni D, Elis A, Konikoff FM: Effect of ezetimibe on the prevalence of cholelithiasis. World J Gastroenterol 2012; 18(40): 5789-5792. doi:10.3748/wjg.v18.i40.5789

22. Oliver $M$ : The clofibrate saga: A retrospective commentary. Brit I Clin Pharmacol 2012; 74(6): 907-910. doi:10.1111/j.1365-2125.2012.04282.x

23. Baffy Gy: Novel strategies in the pharmacotherapy of nonalcoholic fatty liver disease. Central Eur I Gastroenterol Hepatol 2016; 2(2): 54-66.

24. Pap A, Gyökeres T: A hepatobiliaris rendszer endoszkópos vizsgálata (in: Bene L, Gyökeres T, Pap Á/szerk.I: Emésztöszervi endoszkópia 2015), pp. 275-374).

25. DiMagno MJ, Spaete JP, Vallard DB, Erik-Jan Wamsteker, Saini SD: Risk models for post-ERCP pancreatitis (PEP), smoking and chronic liver disease are predictors of protection against PEP. Pancreas 2013: 42(6): 996-2003. doi:10.1097/MPA.0b013e31827e95e9
26. He QB, XU T, Wang J, Li YH, Wang L, Zou XP: Risk factors for post-ERCP pancreatitis and hyperamylasemia: a retrospective single-center study.J Dig Dis 2015; 16(8): 471-478. doi:10.1111/1751-2980.12258

27. de Miguel-Yanes J, Méndez-Bailon M, Jiménez-Garcia R, González-Asanza C, Hernández-Barrera V, Muñoz-Rivas N, et al: Tendencies and outcomes in endoscopic biliary sphincterotomies among people with or without type 2 diabetes mellitus in Spain, 2003-2013. Rev Esp Enferm Dig 2016; 3: 386-393. doi:10.17235/reed.2016.4276/2016

28. Gruberg L, Weissmann NJ, Waksman RF, Fuchs S, Deible R, Pinnow EE, et al.: The impact of obesity on the short-term and long-term outcomes after percutaneous coronary intervention: the obesity paradox? I Am Coll Cardiol 2012; 39: 578-584.

29. Terho PM, Leppäniemi AK, Mentula PJ: Laparoscopic cholecystectomy for acute calculous cholecystitis: a retrospective study assessing risk factors for conversion and complications. World J Emerg Surgery 2016; 11: 54-62. doi:10.1186/s13017-016-0111-4

30. de Miguel-Yanesa JM, Méndez-Bailéón $M$, Jiménez-Garcia R, HernándezBarrera $\mathrm{V}$, Pérez-Farinás $\mathrm{N}$, Turégano $\mathrm{F}$, et al: Open vs. laparoscopic cholecystectomies in patients with or without type 2 diabetes mellitus in Spain from 2003 to 2013. Hepatobiliary Pancr Dis 2016; 15(6): 525-532. doi:10.1016/51499-3872(16)60091-7

31. Lowndes B, Thiels CA, Hasberrmann EB, Bingener J, Hallbeck S, Yu D: Impact of patient factors on operative duration laparoscopic cholecystectomy: evaluation from the National Surgical Quality Improvement Program Database. Am JSurg 2016;212:289-2967. doi:10.1016/j.amjsurg.2016.01.024 